\title{
PKM PENDAMPINGAN PRODUKSI TAHU BERBASIS TEKNOLOGI DAN MANAJEMEN KEUANGAN DI SENTRA INDUSTRI TAHU NGLONGSOR, TRENGGALEK
}

\author{
Titik Purwati ${ }^{1}$, Nurmala Hindun ${ }^{2}$ \\ ${ }^{1,2)}$ IKIP Budi Utomo, Malang, Jawa Timur, Indonesia \\ ${ }^{1 *}$ Email: titikpurwati62@gmail.com \\ ${ }^{2}$ Email: nurmalahindun@yahoo.co.id
}

\begin{abstract}
Tofu is a nutrient-rich snack. Soy-based. One area that produces tofu is the Corah Mulyo, Nglongsor, Tugu, which is the Tofu Industry Center in Trenggalek Regency. As confectionary from simple and traditional industrial processed products, hygiene and waste disposal aspects are largely lacking in careful attention. Soybeans are ground into mush, boiled, filtered, quenched and dregs separated, the essence is boiled again, given liquid vinegar, clots, squeezed and printed. The remaining juice is a waste. Team of PKM P2M IKIP Budi Utomo Malang introduced the management of the production process that is efficient and free from waste and also provides an understanding of the financial governance of business results. With a different milling machine, soybeans are ground to produce essence and pulp. Boiled quintessence is given a liquid nautical juice, clots, squeezed and printed. The remaining juice can be used for making drinks, odorless and environmentally friendly. Methods and approaches through transformation and mentoring. End of activities, Team of PKM (1) Transform hygienic tofu production processes, (2) Ability to operate soybean grinding machines, (3) Socialize handling of production processes with sanitation and a clean work environment, (4) Understand the value of financial governance results business tofu.
\end{abstract}

Keyword: tofu industry center, mentoring, nautical juice, Corah Mulyo Nglongsor

\section{PENDAHULUAN}

Kabupaten Trenggalek merupakan kawasan yang disebut sebagai bagian dari wilayah selatan Prop. Jawa Timur. Sebagian besar masyarakat bermata pencaharian sebagai petani (buruh tani), nelayan, buruh pabrik, tukang batu, dan sebagian kecil berwirausaha (dalam taraf usaha rumahan) seperti usaha rumahan tahu. Salah satu usaha rumahan adalah milik Pak Muyono Riyanto dan Pak Suprayitno di sentra usaha tahu Nglongsor. Kedua wirausaha tahu berlokasi di sentra usaha tahu dusun Corah Mulyo, Nglongsor, Tugu, Kab. Trenggalek. Usaha rumahan tahu Pak Muyono Riyanto dirintis sejak tahun 96-an. memiliki karyawan sebanyak 2 orang. Kedua orang karyawannya adalah tetangga terdekat saja. Demikian halnya usaha tahu milik Pak Suprayitno. Usaha tahu Pak Suprayitno memiliki 2 orang karyawan yang juga merupakan tetangga dekat. Karena itu usaha mereka berdua tergolong sebagai usaha rumahan (home industri). Rambu sentra industri di Kabupaten Trenggalek dapat dilihat pada Gambar 1.

Kegiatan usaha tahu yang telah dijalani selama lebih dari 20 tahun, usaha pak Muyono Riyanto dan pak Suprayitno ini seperti telah mengalami stagnasi, karena pangsa pasar yang tetap namun di sisi lain, muncul pengrajin usaha tahu yang baru sehingga menjadikan tingkat persaingan yang semakin ketat. Meskipun dalam kondisi yang demikian usaha rumahan tahu Pak Muyono Riyanto dan Pak Suprayitno tetap bertahan hingga sekarang. 


\section{Tahu Sebagai Lauk Utama}

Kedelai adalah salah satu jenis tanaman polong-polongan yang menghasilkan protein. Karena itu tanaman ini tergolong tanaman pangan yang memiliki nilai strategis terpenting di dunia setelah padi dan jagung. Banyak bahan pangan dan bahan penunjang untuk pangan berasal dari kedelai.
Mulai dari makanan sampai untuk menghasilkan minyak kedelai. Kebutuhan kedelai di Indonesia mencapai 2,9 juta ton setiap tahun. Sebesar 2,6 juta ton untuk memenuhi kebutuhan masyarakat berbentuk makanan (Dirjentanpan, 2013), yang berupa tempe dan tahu.

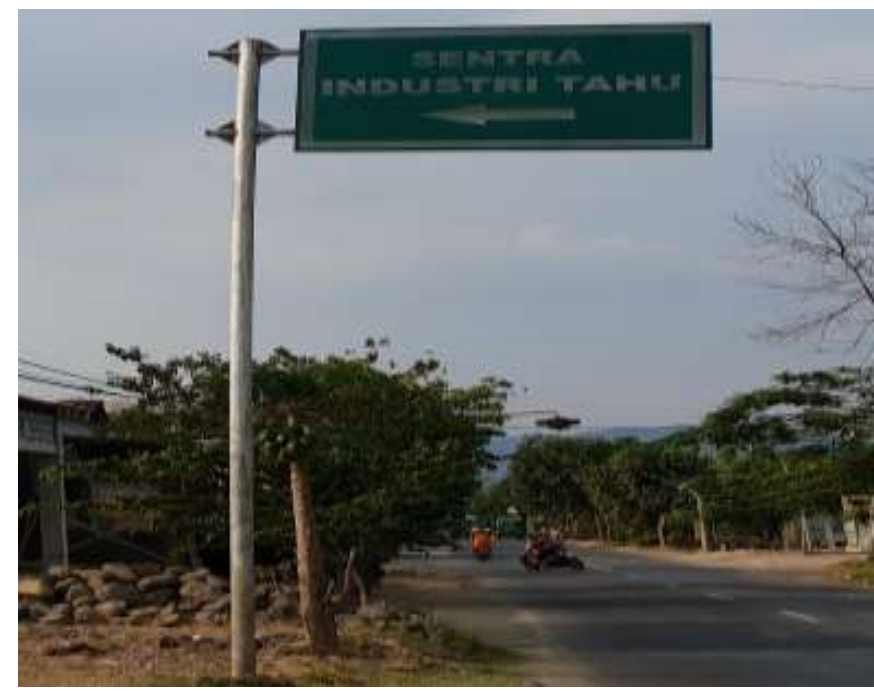

Gambar 1. Rambu Sentra Industri (Sumber: doc. Pribadi, 2018)

Sisanya, 600 ribu ton untuk kebutuhan non pangan. Pada sisi lain, kemampuan produksi kedelai nasional hanya mampu mencapai $42 \%$ dari kebutuhan per tahun, mengingat pertumbuhan Industri (Putri, 2014). Untuk memenuhi kekurangan maka dilakukan kebijakan impor.

Kabupaten Trenggalek merupakan salah satu sentra penghasil kedelai di Jawa Timur (Litbang pertanian, 2015). Meskipun demikian para wirausaha tempe dan tahu lebih suka menggunakan kedelai impor. Alasannya, kedelai impor bentuknya besarbesar, berwarna cerah. Senantiasa tersedia stok cadangan.

\section{Pembuatan Tahu di Nglongsor, Tugu,} Kab. Trenggalek

Bahan-bahan yang disiapkan untuk proses pembuatan tahu meliputi: (1) kedelai. (2) cairan cuka yang berfungsi sebagai media penggumpal saripati kedelai agar berproses menjadi tahu. Proses produksi dimulai dari:

1. Penggilingan kedelai. Kedelai digiling dengan mesin giling sehingga menghasilkan bubur kedelai mentah.
Pada tahapan ini, belum ada pemisahan antara saripati kedelai yang akan diproses menjadi tahu dengan ampasnya. Genset da mesin giling kedelai dapat dilihat pada Gambar 2. Tempat pengolahan kedelai menjadi tahu dapat dilihat pada Gambar 3.

2. Bubur kedelai dengan kondisi kental kemudian direbus dengan menggunakan uap panas yang dihasilkan dari ketel uap yang dibuat secara sederhana. Ketel uap terbuat dari drum berbahan plat bekas yang dikonstruksi sedemikian rupa. Drum diisi air dipanasi hingga menghasilkan uap panas. Proses pemanasan, agar berbiaya hemat, media pembakaran tidak menggunakan kayu bakar namun menggunakan buangan dari gergajian kayu. Bubur kedelai dari proses giling dapat dilihat pada Gambar 4.

3. Proses penyaringan cairan bubur kedelai dilakukan langsung di atas tempat penampungan sari kedelai yang berada di bawah alat penyaringan. Tempat 
penampungan sari pati kedelai itu (berupa bak penampungan) terletak di sebelah tempat penggodogan bubur kedelai namun posisinya yang lebih rendah. Proses penyaringan dapat dilihat pada Gambar 5.

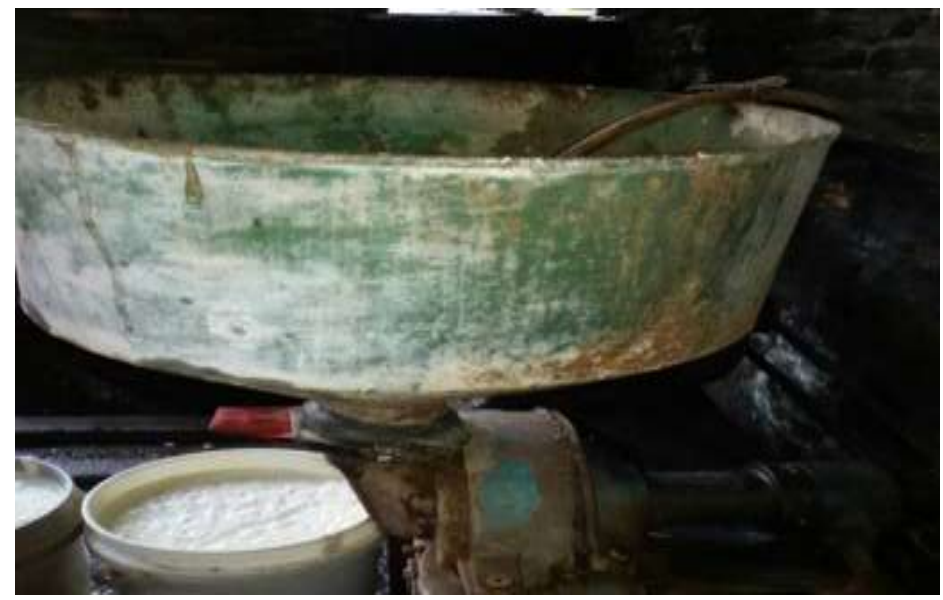

Gambar 2. Genset dan Mesin Giling Kedelai (Sumber: doc. Pribadi, 2018)

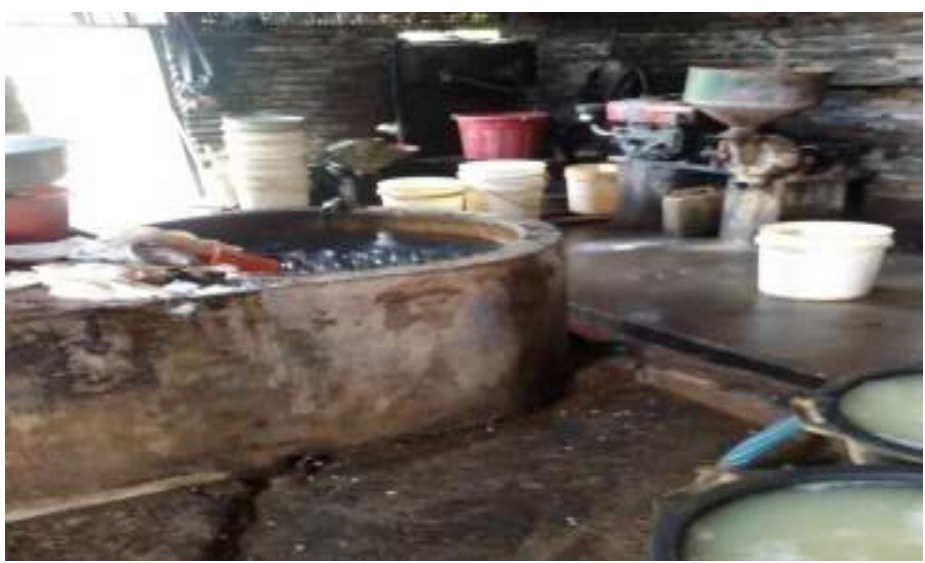

Gambar 3. Tempat Pengolahan Kedelai menjadi Tahu (Sumber: doc. Pribadi, 2018)

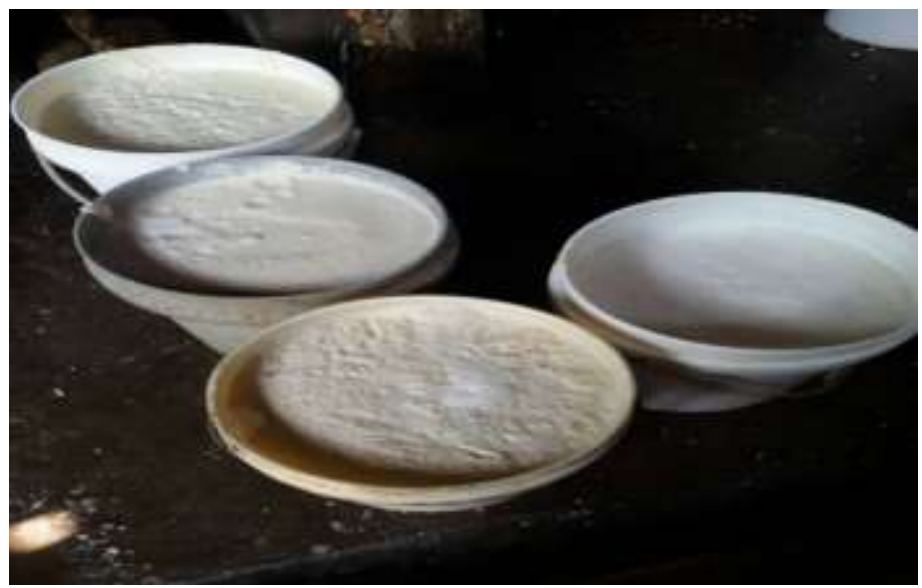

Gambar 4. Bubur Kedelai dari Proses Giling (Sumber: doc. Pribadi, 2018)

4. Ampas kedelai setelah melalui proses penyaringan dan pemerasan ditempatkan pada wadah yang terpisah. Biasanya ampas kedelai dari pembuatan tahu ini dimanfaatkan untuk pembuatan tempe menjes atau diberikan untuk pakan hewan; kambing atau sapi.

5. Sari pati dari bubur kedelai yang ada di bak penampungan segera diberi cairan cuka, kemudian diaduk hingga merata 
agar berproses dan terjadi penggumpalan dan mengendap ke bagian bawah dari bak penampungan.

6. Sari pati dari bubur kedelai yang sudah dicampur dengan cairan cuka di Bak penampungan, bagian atas diambil sebagian untuk dicadangkan sebagai bahan dalam proses berikutnya secara terus menerus. Cairan yang mengandung saripati kedelai di bagian bawah bak penampungan diambili dan dipindahkan ke bak penampungan cetak untuk pencetakan menjadi tahu.

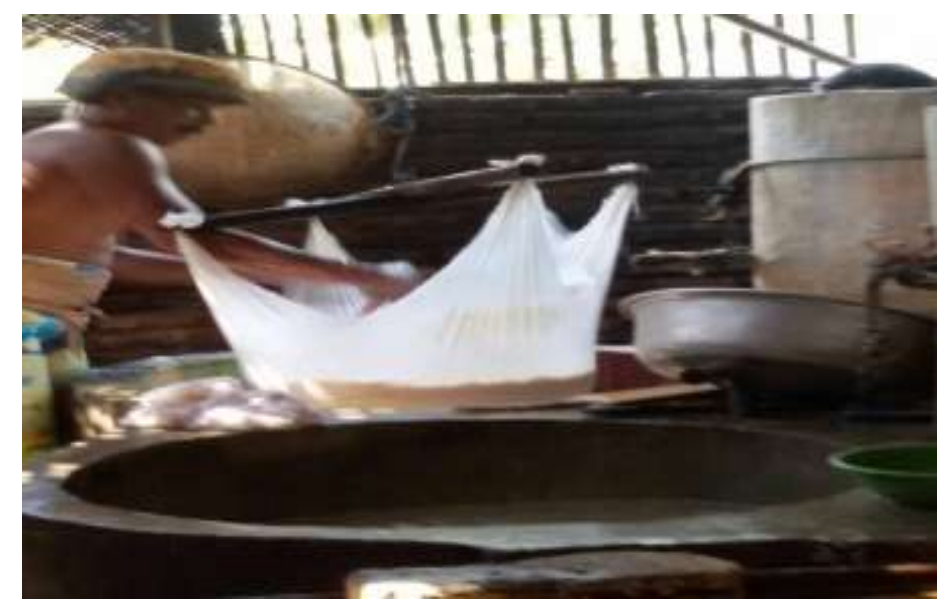

Gambar 5. Proses Penyaringan untuk Memisahkan Saripati dari Serat (Ampas) (Sumber: doc. Pribadi, 2018)

7. Pada bak penampungan cetak tahu, telah disiapkan alat-alat yang terbuat dari bambu yang akan mencetak untuk menjadi tahu. Alat cetak dari bambu diberi kain kasa untuk alas di bagian bawah. Setelah cairan dipindahkan semua pada bak penampungan cetak, kemudian diberi kain kasa lagi, untuk bagian atas selanjutnya diberi alat cetak dari bambu juga. Berikutnya dilakukan pengepresan dengan cara menindih alat cetak yang terbuat dari bambu dengan batu-batu besar. Bak penampungan cetak tahu, di bagian bawah terdapat lubang- lubang yang dijadikan saluran sisa perasan saripati tahu. Pencetaakan tahu dapat dilihat pada Gambar 6.

Sisa perasan menjadi cairan limbah yang dapat menimbulkan bau yang sangat tidak nyaman. Karena itu cairan limbah dari perasan sari pati tahu harus dibuang dengan cara mengalirkan ke bagian yang jauh dari pemukiman. Sari pati kedelai yang telah menggumpal setelah dilakukan pengepresan, dipindahkan ke bagian pentirisan cairan. Akhirnya sari pati kedelai menjadi tahu. Rumah dan tempat usaha mintra dapat dilihat pada Gambar 7.

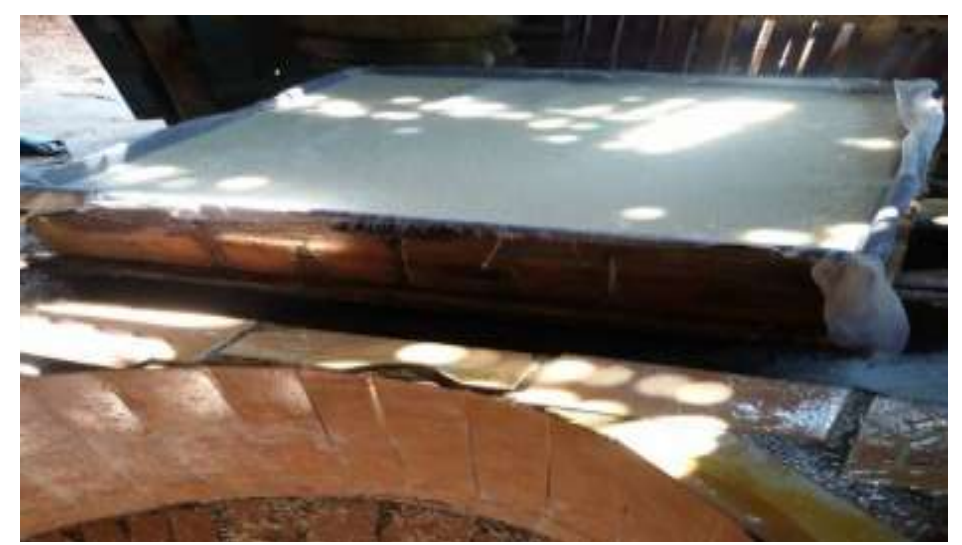

Gambar 6. Pencetakan Tahu (Sumber: doc. Pribadi, 2018) 


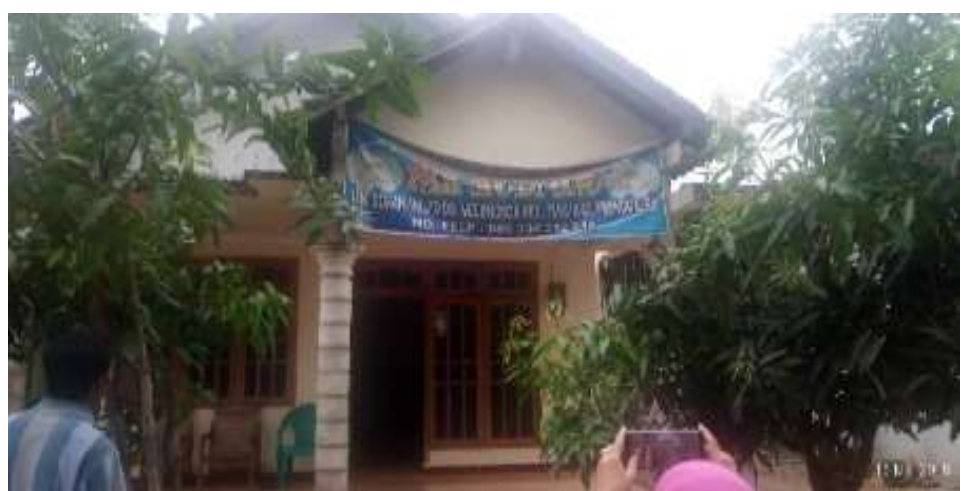

Gambar 7. Rumah dan Tempat Usaha Mitra (Sumber: doc. Pribadi, 2018)

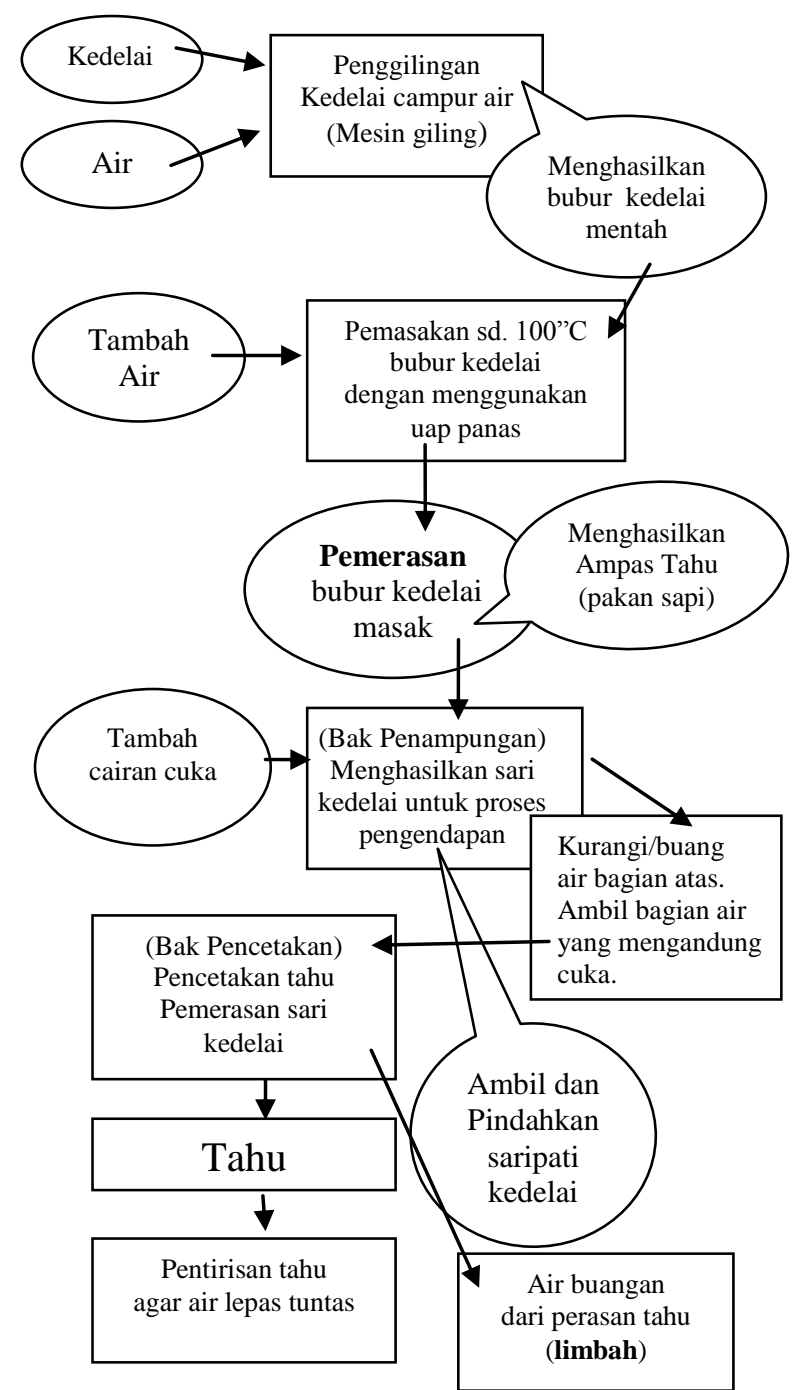

Gambar 7. Rangkaian Urutan Proses Pengolahan Tahu

\section{METODE PELAKSANAAN}

Metode untuk implementasi program kemitraan masyarakat dengan menggunakan metode survey, observasi dan partisipatori. Sedangkan untuk menyusun program aksi dilakukan melalui kegiatan diskusi dengan harapan program aksi yang dihasilkan merupakan program aksi yang dibutuhkan mitra. Oleh karena itu dalam implementasi program kemitraan masyarakat ini mitra 
dilibatkan mulai dari perumusan dalam perencanaan kebutuhan sesuai kebutuhan mitra.

Dalam proses diskusi ditemukan persoalan yang perlu dipecahkan. Bahwa dalam proses produksi harus melalui rangkaian kegiatan produksi yang panjang sehingga memboroskan waktu dan tenaga. Dalam diskusi antara Tim PKM dengan mitra dan peserta diskusi lainnya, ditemukan pula bahwa selama ini, mitra tidak melakukan kegiatan pembukuan yang memadai. Oleh karena itu perlu dilakukan pemahaman tentang urgensinya pencatatan ke dalam buku keuangan/jurnal harian yang sederhana. Metode partisipatori, merupakan bentuk metode untuk proses transformasi ketrampilan dalam mana mitra didorong untuk berlatih secara aktif untuk mengoperasikan mesin giling kedelai agar mitra teradaptasi dan menjadi segera mumpuni dalam mengoperasikan mesin giling.

Implementasi dari metode transformasi berupa kegiatan-kegiatan pendampingan yang berkelanjutan terhadap target-target yang menjadi objek dalam mitra telah mengalami stagnasi dalam pencapaian baik pada tata kelola produksi maupun tata kelola dalam pencatatan/pembukuan keuangan. Kegiatan pendampingan produksi tahu dapat dilihat pada Gambar 8.

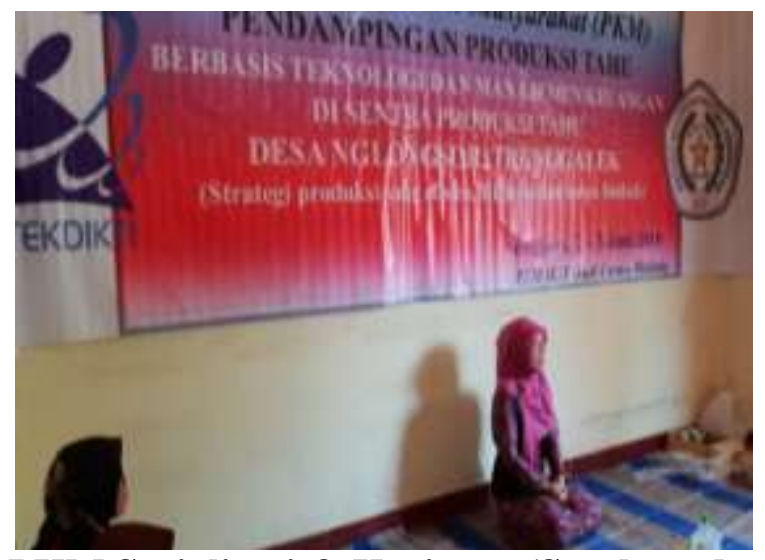

Gambar 8. Tim PKM Sosialisasi \& Kegiatan (Sumber: doc. Pribadi, 2018)

\section{HASIL DAN PEMBAHASAN}

\section{A. Hasil Pengabdian Kepada Masyarakat}

PKM pendampingan produksi tahu berbasis teknologi dan manajemen keuangan di sentra usaha tahu dusun Corah Mulyo desa Nglongsor, Kecamatan Tugu, Kab. Trenggalek. Penduduknya lebih dari $80 \%$ telah puluhan tahun menekuni kegiatan usaha dengan memproduksi tahu. Sehingga telah mengalami kemapanan (established). Tahu yang dihasilkan dalam bentuk; (1) tahu mentah dan (2) tahu goreng. Hasil dari kegiatan produksi dipasarkan ke pasar-pasar tradisional di seluruh wilayah Kabupaten Trenggalek. Lokasi kawasan sentra industri tahu dapat dilihat pada Gambar 9.

Pak Muyono, salah satu warga dusun Corah Mulyo, Nglongsor, kecamatan Tugu, Kab. Trenggalek. Juga tetangga dan warga sekitarnya, memiliki usaha sebagai pengrajin tahu mewarisi dan meneruskan usaha dari para orang tuanya. Usaha produksi tahu yang dikelola Pak Muyono dan isterinya, setiap hari memulai kegiatan usaha dari pk. 03.00 dini hari.

Menuju tempat untuk buka lapak di pasar yang biasa ditempatinya. Baru akan pulang kembali ke rumah pada pukul 09.00 siang. Sesampainya di rumah pak Muyono langsung mengendalikan kegiatan produksi yang mempekerjakan 2 orang karyawan. 1 (satu) orang laki-laki untuk bagian produksi dan 1 (satu) orang wanita bekerja untuk menggoreng tahu. Mengubah pola kebiasaan, perilaku dan pola kerja yang telah menjadi rutinitas selama puluhan tahun seperti yang dijalani pak Muyono dan pekerjanya memerlukan waktu untuk memprosesnya. 


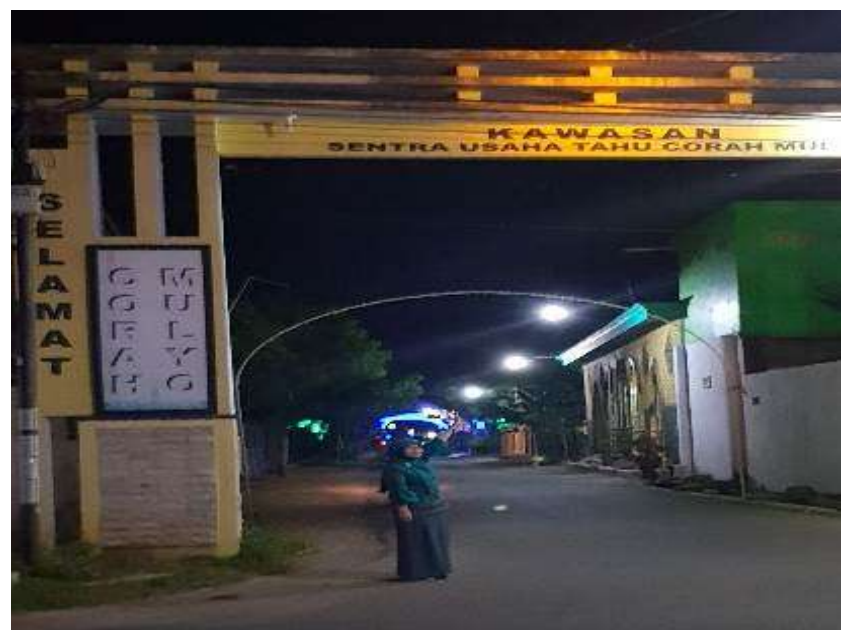

\section{Gambar 9. Gerbang masuk Kawasan Sentra Industri Tahu}

(Sumber: doc. Pribadi, 2018)

Sifat resisten terhadap perubahan yang diintrodusir oleh Tim PKM menjadi bagian dari upaya dan kerja keras tersendiri yang harus dilalui.

\section{Capaian kegiatan kesatu}

"Musyawarah rencana dan kesepakatan penetapan serangkaian kegiatan PKM di desa Nglongsor; Sentra Usaha Tahu"

Tim PKM melakukan kegiatan orientasi ulang untuk lebih memahami lokasi yang akan menjadi sasaran dalam pelaksanaan kegiatan PKM. Orientasi dilaksanakan hari ahad tanggal 22 April 2018. Dalam kegiatan orientasi telah dilakukan musyawarah yang dilangsungkan di rumah Bapak Muyono. Selain dihadiri Pak Muyono dan keluarganya juga dihadiri pengrajin lainnya. Perserta kegiatan PKM dapat dilihat pada Gambar 10.

Musyawarah itu meliputi tentang waktu pelaksanaan, pemilihan tempat kegiatan, kepesertaan dalam kegiatan dan ketersediaan sumber daya listrik. Dalam musyawarah telah menyepakati bahwa pelaksanaan kegiatan pelatihan dilakukan di rumah Pak Muyono. Sedangkan pelaksanaan kegiatan, senantiasa diatur ulang dengan melalui kesepakatan dan kepesertaan pelatihan terbuka bagi para pengrajin tahu di dusun Corah Mulyo, Desa Nglongsor, Tugu, Trenggalek. Momen setelah kegiatan musyawarah dapat dilihat pada Gambar 11.

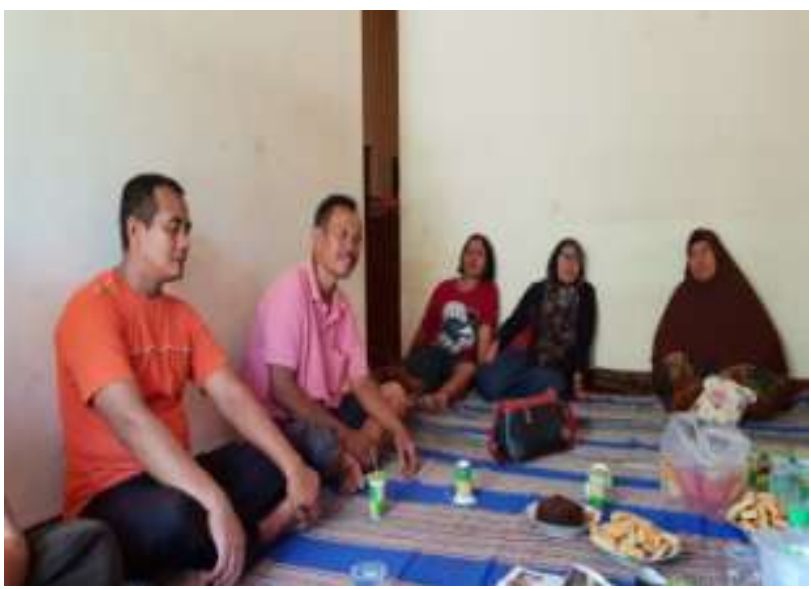

Gambar 10. Peserta Kegiatan PKM (Sumber: doc. Pribadi, 2018) 


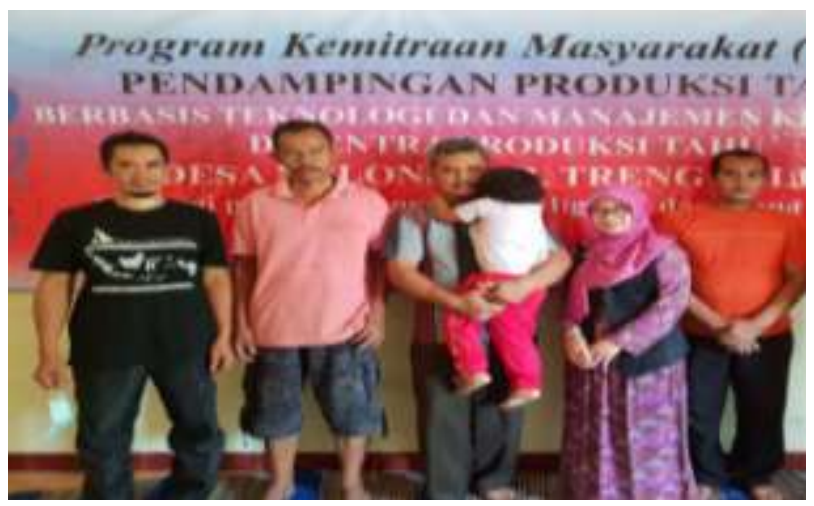

Gamba 11. Moment Setelah Kegiatan (Sumber: doc. Pribadi, 2018)

\section{Capaian kegiatan kedua}

"Pendampingan pelatihan produksi tahu dengan menggunakan mesin giling kedelai"

Tim PKM IKIP Budi Utomo, hari Sabtu dan Ahad, 2 dan 3 Juni 2018 melakukan kegiatan pelatihan penggunaan dan operasionalisasi proses produksi dengan menggunakan peralatan dan mesin produksi tahu yang diintrodusir Tim PKM. Dalam rangka pelaksanaan pelatihan di lokasi PKM, dusun Corah Mulya, desa Nglongsor, Tugu, Trenggalek Tim PKM telah menyiapkan rendaman kedelai selama 6 (enam) jam sebelumnya. Berlatih sebagai operator mesin giling (mode yang baru) dapat dilihat pada Gambar 12.

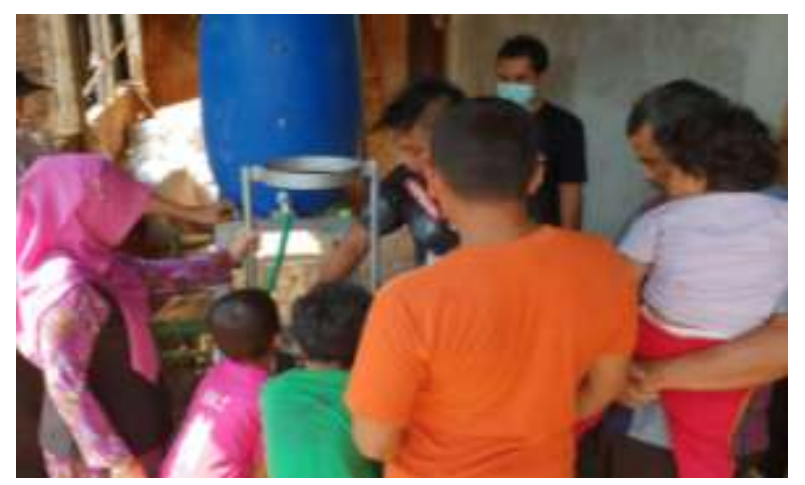

Gambar 12. Berlatih Sebagai Operator Mesin Giling (Mode yang Baru)

(Sumber: doc. Pribadi, 2018)

a. Hari Pertama, Sabtu, 2 Juni 2018.

Operasionalisasi peralatan dan mesin produksi untuk pertama kali dioperasikan oleh Narasumber yang dibawa oleh Tim PKM dari IKIP Budi Utomo Malang. Diawali dengan melakukan perakitan peralatan pendukung mesin produksi. Menset-up peralatan dan mesin produksi rakitan Tim PKM IKIP Budi Utomo tidak memerlukan ruangan yang besar. Bisa disetup pada ruang yang hanya berukuran $3 \times 4$ meter saja. Setelah rampung dilakukan pengoperasian proses produksi. Sementara peserta dari pengrajin tahu memperhatikan proses operasionalisasi peralatan dan mesin produksi tahu. Proses operasionalisasi peralatan dan mesin produksi dijalankan secara nyata. Kegiatan pelatihan produksi tahu dengan cara melakukan proses pengolahan kedelai yang sudah disiapkan Tim PKM yang dibawa dari Kota Malang. Langkah demi langkah dijalankan oleh Narasumber sampai selesai proses pencetakan tahu mentah.

Setelah rampung mendemonstrasikan kepada para peserta diberikan kesempatan untuk tanya jawab untuk memahamkan mekanisme kerja dan kemampuan mesin 
giling kedelai yang baru dioperasikan. Sebelum mengakhiri pertemuan di hari pertama, Tim PKM mempersiapkan bahan untuk pelatihan di hari berikutnya, yakni persiapan, antara lain merendam kedelai yang akan digunakan kegiatan pelatihan dengan menggunakan milik Pak Muyono sebanyak 5 (lima) kg.

\section{b. Hari kedua, Ahad, 3 Juni 2018}

Pelaksanaan pelatihan menginstal peralatan dan mesin produksi tahu dilakukan oleh peserta pelatihan untuk hari kedua, Narasumber hanya bertindak sebagai fasilitator atau hanya melakukan kegiatan pendampingan. Target pencapaian kegiatan pelatihan peserta adalah kemampuan dalam meng-instalasi mesin giling kedelai dengan kapasitas $25 \mathrm{Kg} /$ per jam. Meliputi; (1) pelepasan tutup mesin giling. pemasangan saringan di dalam mesin giling kedelai. (3) Pemasangan batu penghalus atau penggiling kedelai. (4) Penutupan kembali mesin untuk dioperasikan. (5) Dioperasikan sesuai kebutuhan. (6) Membuka kembali setelah dioperasikan untuk dibersikan dan dirapihkan. Installasi mesin giling kedelai untuk produksi tahu dapat dilihat pada Gambar 13. Berlatih mengoperasikan mesin giling yang langsung pisahkan sari pati dan ampasnya dapat dilihat pada Gambar 14 . Bentuk mesin giling yang dapat secara langsung memisahkan sari pati dan ampasnya dapat dilihat pada Gambar 15.

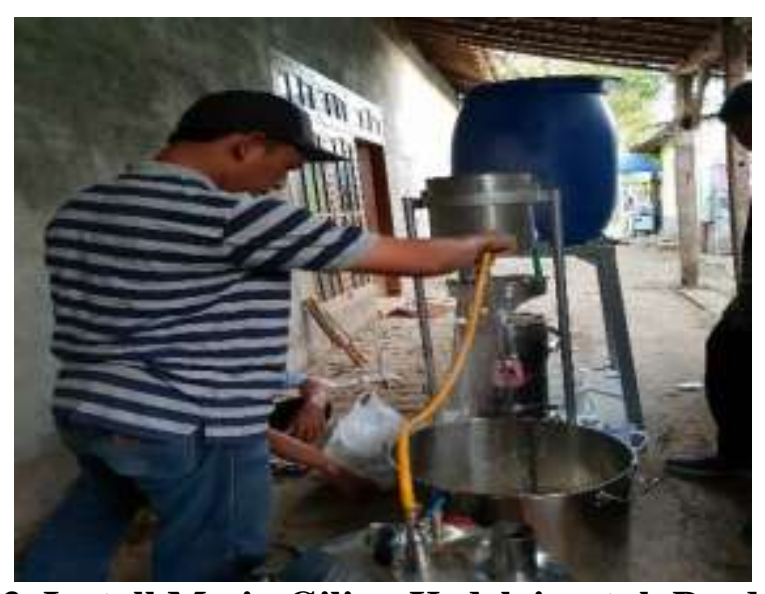

Gambar 13. Install Mesin Giling Kedelai untuk Produksi Tahu (Sumber: doc. Pribadi, 2018)

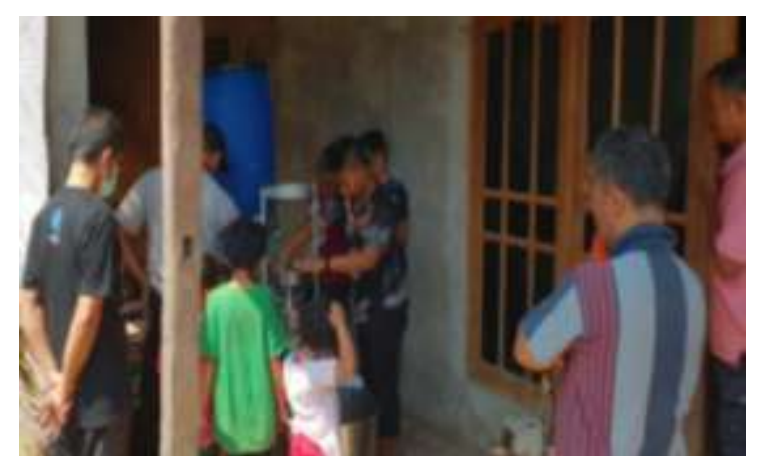

Gambar 14. Berlatih Mengoperasikan Mesin Giling yang Langsung Pisahkan Sari Pati dan Ampasnya (Sumber: doc. Pribadi, 2018) 


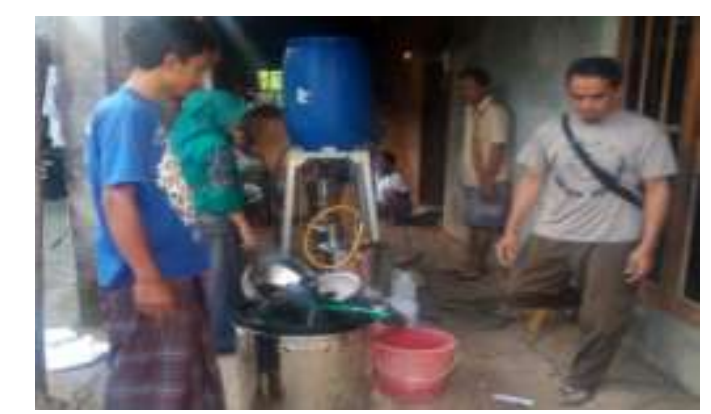

\section{Gambar 15. Mesin Giling Langsung Pisahkan Sari Pati dan Ampas (Sumber: doc. Pribadi, 2018)}

Adapun kedelai yang digunakan untuk giling kedelai. Target khusus pelatihan di pelatihan operasioalisasi mesin adalah kedelai percobaan yang sudah direndam sebelumnya di hari kedua dimanfaatkan untuk kegiatan pelatihan oleh peserta dengan mengoperasikan peralatan dan mesin produksi dari Tim PKM. Peserta melakukan langkah-langkah seperti yang dipandukan oleh Narasumber praktisi usaha tahu dari Tim PKM IKIP Budi Utomo. Di hari kedua ini, diberikan kepada 2 (dua) orang untuk berlatih mengoperasikan peralatan dan mesin hari kedua dalam pencapaian untuk memiliki kemampuan: (1) mengoperasikan mesin giling kedelai. (2) mengukur penggunaan sari bahari sebagai penggumpal tahu pengganti pemakaian cairan asam cuka. Untuk pelatihan kemampuan proses selanjutnya sama seperti dalam penanganan proses pembuatan tahu pada umumnya. Pemasakan sari pati kedelai dapat dilhat pada Gambar 16. Pengumbulan sari pati tahu dapat dilihat pada Gambar 17.

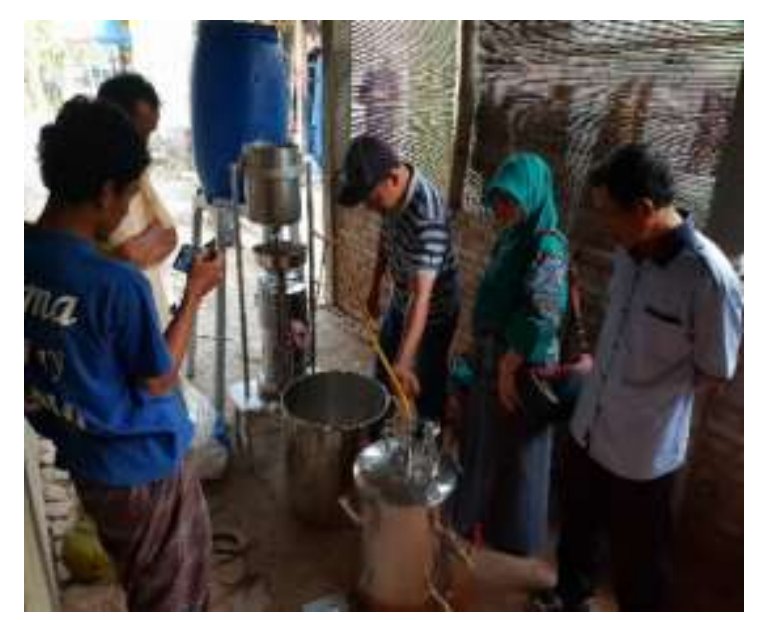

Gambar 16. Pemasakan Sari Pati (Sumber: doc. Pribadi, 2018)

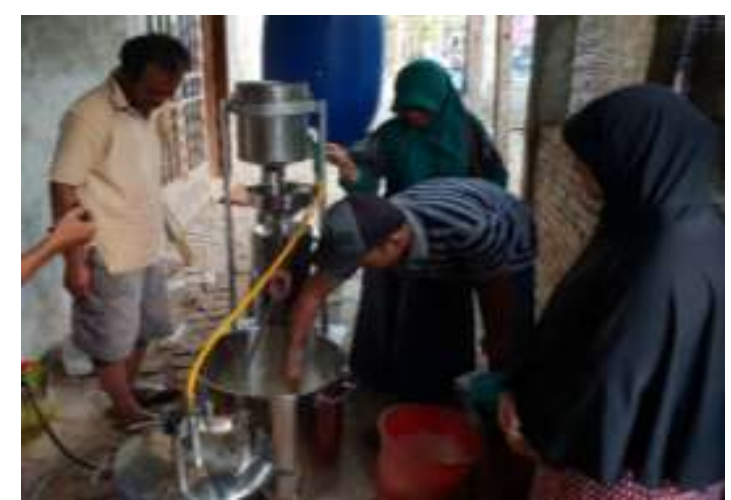

Gambar 17. Penggumpalan Sari Pati Tahu (Sumber: doc. Pribadi, 2018) 


\section{Capaian Kegiatan ketiga}

"Pendampingan lanjut pelatihan produksi tahu dengan menggunakan mesin giling kedelai"

Pendampingan lanjut dalam pelatihan mengoperasikan mesin giling kedelai oleh Tim PKM telah dipandang perlu. Hari Sabtu dan Ahad, 23 \& 24 Juni 2018 Tim PKM IKIP Budi Utomo melakukan kunjungan ulang untuk melakukan pendampingan lanjutan. Sebab, karakteristik sebuah mesin yang bekerja pada suatu waktu bisa mengalami kendala yang sulit diprediksikan. Karena itu pembinaan yang berkelanjutan terus dilakukan oleh Tim PKM IKIP Budi
Utomo. Kegiatan pendampingan dalam pelatihan lanjutan. Untuk pendampingan dalam pelatihan mengoperasikan mesin giling kedelai ini, demi mempertimbangkan waktu untuk kegiatan maka hanya diikuti oleh 4 orang dalam satu hari. Hari Sabtu, 23 Juni 2018 diikuti 2 (dua) orang berlatih dan 2 orang menjadi pemantau. Demikian pula di hari berikutnya. Ahad, 24 Juni 2018, Tempat pelaksanaan pendampingan pelatihan tetap dilaksanakan di rumah Pak Muyono. Berlatih proses memasak dengan mesin giling baru dapat dilhat pada Gambar 18. Cetakan tahu dengan aneka macam bentuk dapat dilhat pada Gambar 19.

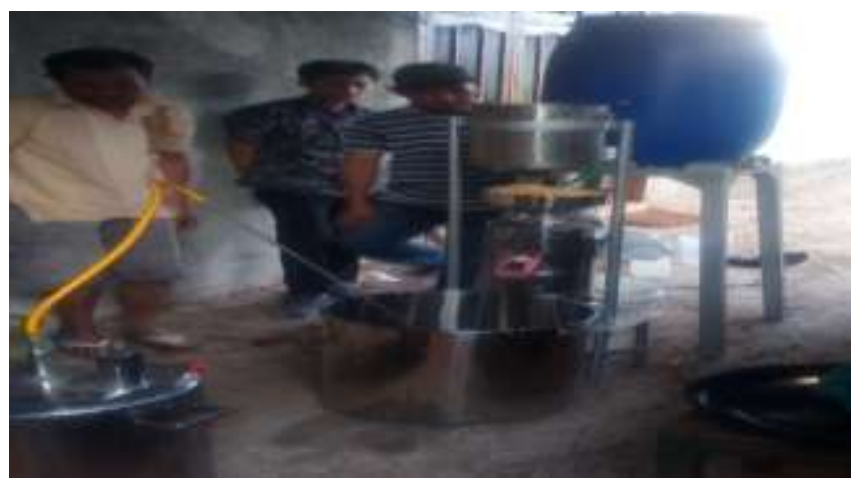

Gambar 18. Berlatih Proses Memasak dengan Mesin Giling Baru

(Sumber: doc. Pribadi, 2018)
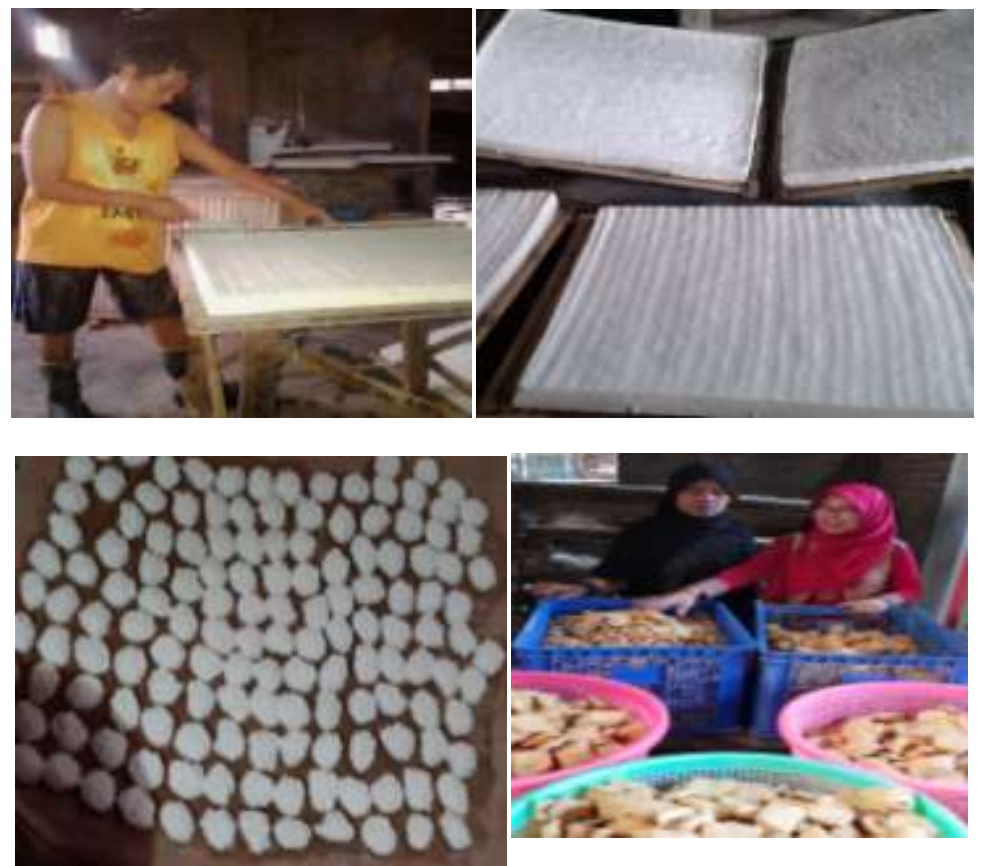

Gambar 19. Cetak Tahu dengan Aneka Bentuk (Sumber: doc. Pribadi, 2018) 


\section{B. Pembahasan}

Tim PKM P2M IKIP Budi Utomo dalam melaksanakan kegiatan pendampingan Produksi Tahu Berbasis Teknologi dan Manajemen Keuangan di Sentra Industri Tahu, Nglongsor, Tugu, Trenggalek. Dalam tataran operasional terkait pelaksanaan pada tingkat teknis operasional dilakukan, penyesuaian. Secara prinsip bahwa semua peralatan digunakan pada saat pelaksanaan PKM. 1) mesin giling kedelai, 2) Ketel uap, 3) panci besar, 4) Bahan penggumpal rebusan air tahu (sari kedelai), 5) alat pencetak tahu serta peralatan lainnya. Untuk meneguhkan bahwa dalam proses produksi dengan menggunakan mesin giling kedelai model baru, bisa memperpendek tahapan proses produksi, sekaligus tidak ada tahapan pemerasan bubur tahu dengan maksud memisahkan saripati dengan serat (ampas).

Sekaligus pula bahwa dalam pembuatan tahu, seluruh peralatan untuk memproses produk harus dijamin higienitasnya dan tidak akan mengalami perubahan/ terkontaminasi. Oleh karena itu Tim PKM menyiapkan seluruh peralatan terbuat dari stainless steel sebagaimana gambar-gambar di atas. Proses giling langsung pisah sari pati dengan ampasnya dapat dilhat pada Gambar 20. Proses memasak sari pati kedelai dapat dilhat pada Gambar 21.

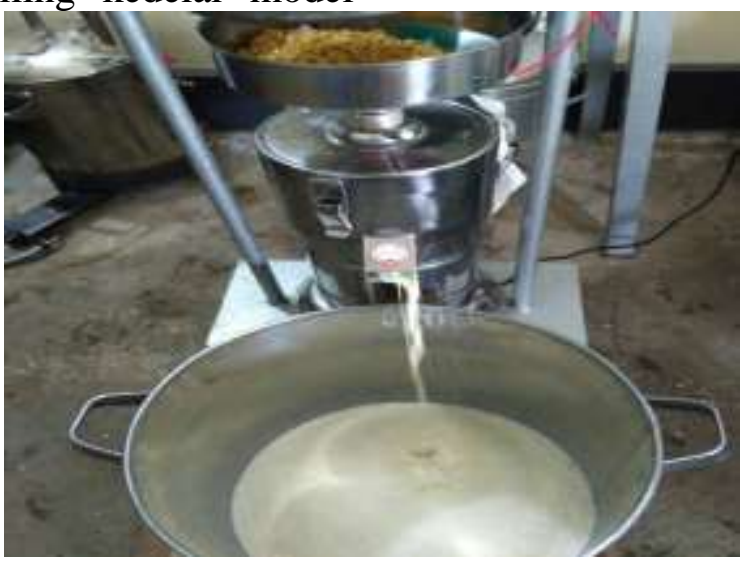

Gambar 20. Proses Giling langsung Pisah Sari Pati dengan Ampas (Sumber: doc. Pribadi, 2018)

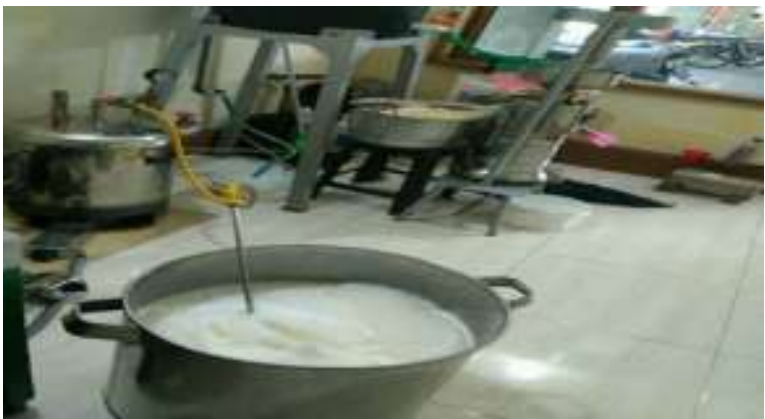

Gambar 21. Proses Memasak Sari Pati Kedelai (Sumber: doc. Pribadi, 2018)

Tim PKM membuat dan menyusun peralatan produksi dengan memperhatikan serangkaian proses produksi. Dimulai dari ukuran bak penampung air yang merupakan bahan pembantu dalam proses. Dialirkan ke dalam drum plastik yang dibuat dengan memperhatikan kebutuhan air saat memproses kedelai. Drum dibuat lubanglubang khusus sebaai penanda untuk kecukupan air yang diperlukan. Posisinya dirancang tinggi melebihi ketinggian mesin giling kedelai sehingga kendali pemenuhan kebutuhan air sangat mudah. Hanya dikendalikan dari kran yang tersanding pada sisi yang telah disesuaikan untuk kemudahan jangkauan. Layout posisi rangkaian peralatan mesin ditempatkan sesuai kebutuhan dengan memperhatikan 
kenyamanan pengoperasiannya. Peralatan pendukung serba stainless steel dapat dilihat pada Gambar 22.

Peserta pelatihan antusias dalam berlatih menjalankan alat yang dikenalkan Tim PKM IKIP Budi Utomo dan telah menerapkannya. Dalam proses produksi diperoleh hasil yang lebih efesien waktu dan energi tenaga yang tidak melelahkan sebagaimana cara yang lama. Gerbang utama sentra industri dapat dilhat pada Gambar 23. Adapun urutan kerja produksi tahu yang diintrodusir oleh Tim PKM P2M IKIP Budi Utomo kepada Mitra dapat dilihat pada Gambar 24.

Upaya untuk memberikan pemahaman dalam tata kelola keuangan dari hasil usaha tahu, mengingat kondisi tingkat Pendidikan mitra adalah rendah maka pelatihan laporan keuangan untuk membantu kedua mitra dalam membuat laporan keuangan diberikan laporan keuangan sederhana agar mitra dapat menjalankan pencatatan. Laporan keuangan sederhana ini meliputi pencatatan keluar masuknya uang dan keluar masuknya bahan baku utamanya kedelai dan minyak. Selain itu juga keluar masuknya barang jadi. Pencatatan keuangan ini penting (Andreas, 2011) bagi mitra antara lain agar mempermudah bila mencari modal usaha pada pihak ketiga, keuangan usaha dan pribadi bisa terpisahkan, maksud lain lagi adalah bisa diketahui berapa penghasilan mitra setiap harinya, setiap pekan, setiap bulan dan penghasilan rata-ratanya. Juga diketahui waktu-waktu tanggal maupun bulan kapan penghasilannya tinggi dan kapan rendah. Laporan sederhana ini bisa digunakan membuat keputusan untuk proses produksinya dan belanja bahan baku. Selama kegiatan pendampingan mitra telah melakukan catatan dengan tertib. Pelatihan tata kelola keuangan hasil usaha tahu dapat dilihat pada Gambar 25.

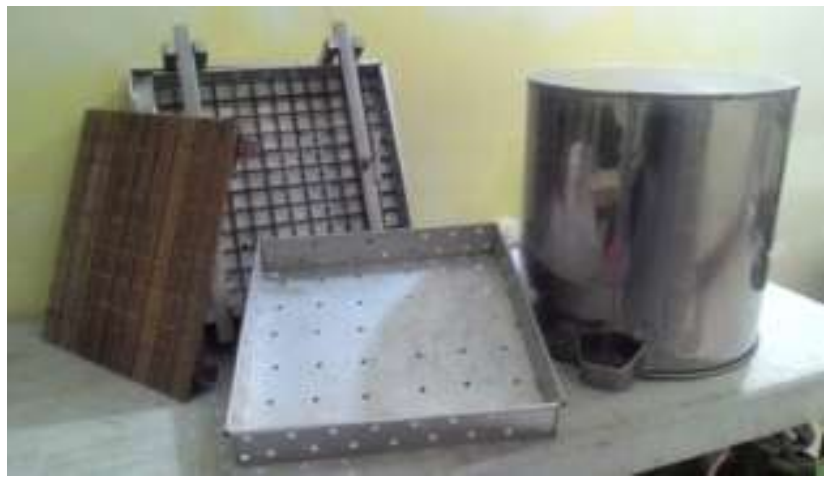

\section{Gambar 22. Peralatan Pendukung Serba Stainless Steel} (Sumber: doc. Pribadi, 2018)

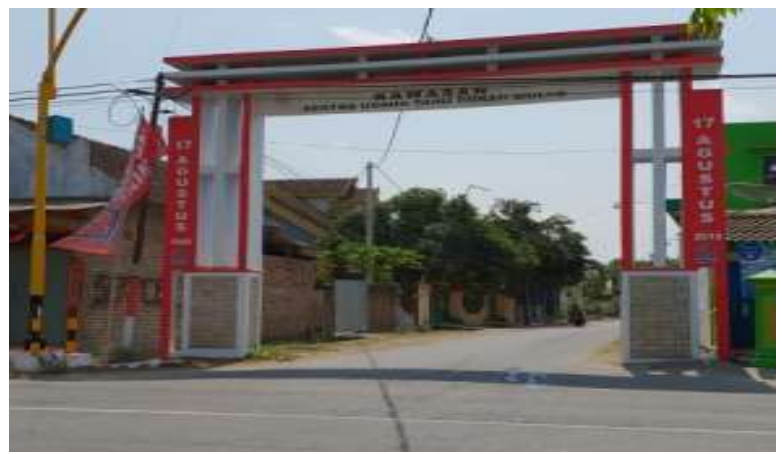

Gambar 23. Gerbang Utama Sentra Industri (Sumber: doc. Pribadi, 2018) 


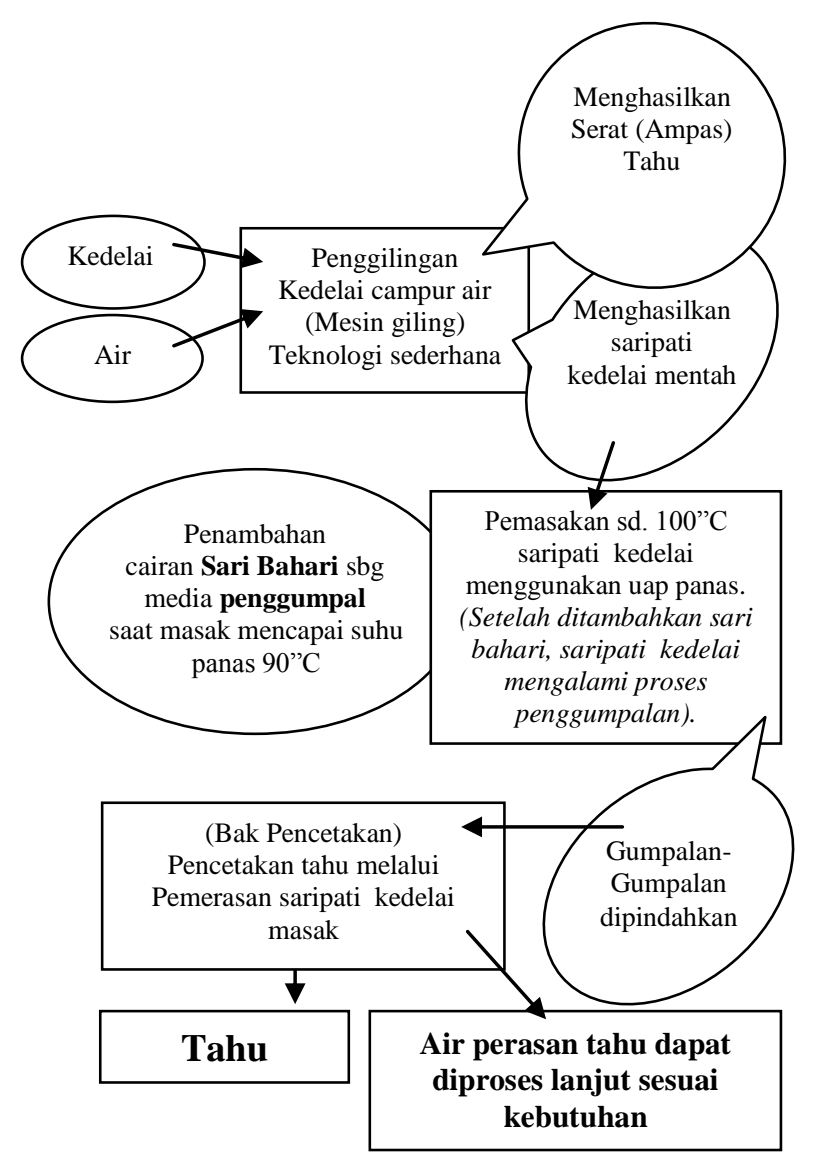

Gambar 24. Rangkaian Urutan Proses Pengolahan Tim PKM IKIP Budi Utomo

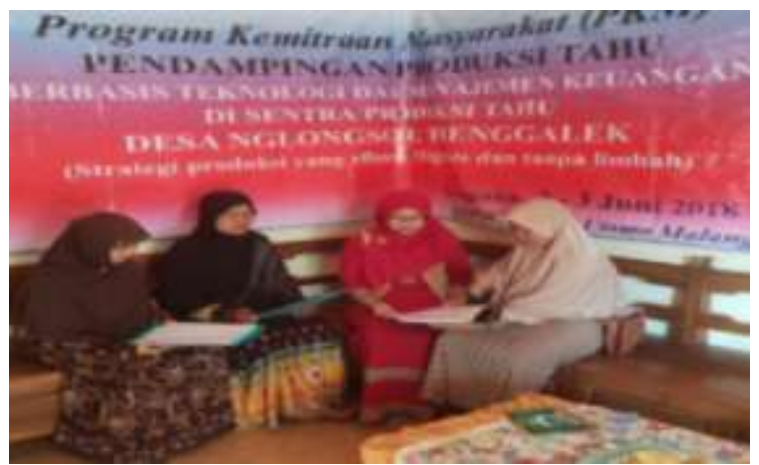

\section{Gambar 25. Pelatihan Tata Kelola Keuangan Hasil Usaha Tahu (Sumber: doc. Pribadi, 2018)}

\section{KESIMPULAN}

Kesimpulan yang dapat dirumuskan sehubungan dengan upaya Tim PKM IKIP Budi Utomo sebagai berikut:

1. Mitra PKM memperoleh wawasan dan pengetahuan baru tentang fungsi, manfaat dan kapasitas mesin giling kedelai yang bisa beroperasi langsung memisahkan antara saripati kedelai dengan serat (ampas).
2. Mitra terbantu dengan penggunaan mesin giling kedelai yang dikenalkan Tim PKM IKIP Budi Utomo. Setelah menggunakan mesin giling kedelai yang diinisiasi Tim PKM maka terdapat satu tahapan proses produksi yang tereliminasi. Dengan demikian menjadi hemat waktu sehingga meringankan beban bagi pekerja.

3. Mitra tidak lagi mengerjakan proses produksi tahu dengan mengeluarkan 
energi dan tenaga yang melelahkan sebagaimana metode lama.

\section{REFERENSI}

Andreas, 2011, Manajemen Keuangan UKM, Yogyakarta: Graha Ilmu

Ditjentanpan (Direktorat Jenderal Tanaman Pangan). 2013, Pedoman Teknis Pengelolaan Kedelai. Jakarta: Kementerian Pertanian.

Putri, 2014, Perkembangan Perindustrian Di Indonesia Dari Tahun Ke Tahun. Wordpress.com. Diunduh, 20 Mei 2017.

Litbang Pertanian, 2015, Panen raya Kedelai di Trenggalek. http://litbang.pertanian. go.id/berita-702-panen-raya-kedelai-ditrenggalek-kedelai-sebagai-bahan bakuindustri-dan-pariwisata.html. Diunduh, 25 Mei 2017.

..........., Cara membuat Tahu Sendiri di Rumah. https://www.youtube.com/ watch? $=8 \mathrm{~g} 3 \mathrm{wBLV7JEs}$. Diunduh, 25 Mei 2017.

Proses Bikin Tahu. https:// www.youtube.com/watch?v=Jntk5F91P Rs. Diunduh, 27 Mei 2017. 